\title{
ULASAN KES:
}

\author{
Norhayati binti Yusoff \\ lwn.
}

\section{Ahmad Shah bin Ahmad Tabrani ${ }^{1}$}

\author{
Mohd Norhusairi Mat Hussin \\ Senior Lecturer, Department of Shariah and Law, \\ Academy of Islamic Studies, \\ University of Malaya, 50603 Kuala Lumpur \\ husairi@um.edu.my
}

\section{PENDAHULUAN}

Kes yang akan diulas ini merupakan kes rayuan mal berkenaan dengan tuntutan harta sepencarian yang dipohon pihak Perayu yang tidak berpuas hati dengan keputusan di Mahkamah Tinggi Syariah Kota Bharu. Kes ini melibat tuntutan harta sepencarian yang dikemukakan terhadap harta alih dan harta tidak alih yang diperolehi disepanjang tempoh perkahwinan yang berlangsung antara pihak-pihak. Kes ini menarik untuk diulas memandangkan terdapat harta yang dituntut dalam tuntutan ini melibatkan wang di dalam Kumpulan Wang Simpanan Pekerja (KWSP) serta harta-harta "moden" seperti saham, World Club Card dan sebagainya.

Dalam kes ini, Mahkamah seolah-olah dilihat membenarkan tuntutan wang KWSP sebagai harta sepencarian sedangkan sudah terdapat fatwa daripada Majlis Fatwa Kebangsaan pada tahun 2005 yang menyatakan bahawa wang KWSP tidak boleh dianggap sebagai harta sepencarian. Sebaliknya, wang KWSP merupakan harta pusaka yang akan diwarisi oleh para waris apabila pencarumnya meninggal dunia. Malah, daripada fatwa yang dikemukakan ini seolah-olah menunjukkan bahawa apabila berlaku perceraian antara pihakpihak, wang KWSP yang dicarum oleh pihak suami atau isteri tidak boleh

\footnotetext{
$1 \quad$ Norhayati binti Yusoff lwn. Ahmad Shah bin Ahmad Tabrani [2008] 27 JH (1) 3350.

* Data-data dalam artikel ini diambil daripada Projek FP030-2016 Universiti Malaya.
} 
dituntut oleh pihak yang satu lagi. Manakala, kes ini menunjukkan fakta yang sebaliknya.

Sungguhpun Mahkamah Syariah tidak mengamalkan konsep binding precedent, keputusan yang dibuat oleh Mahkamah Syariah paling tinggi dalam hierarki Mahkamah Syariah Negeri Kelantan ini tetap akan menjadi rujukan kepada pihak-pihak yang lain selepas kes ini diputuskan. Konsep ini adalah menepati Arahan Amalan No. 1 Tahun 2002 yang menyatakan tentang keputusan Mahkamah yang lebih tinggi hendaklah dihormati dalam kes-kes yang melibatkan persamaan fakta, isu-isu dan undang-undang yang berkaitan. Ulasan kes ini akan membincangkan berkaitan perkara ini serta menyentuh isu-isu ketidakpatuhan kepada prosedur Mal yang menyebabkan kes ini diputuskan dengan "seolah-olah" membenarkan tuntutan harta sepencarian dibuat ke atas wang simpanan di KWSP, dan tidak selari dengan fatwa Majlis Fatwa Kebangsaan. Perkara ini akan diulas dalam ulasan kes di perengganperenggan seterusnya.

\section{FAKTA KES}

Perayu dan Responden telah berkahwin pada 2 Februari 1989 mengikut hukum syarak di Pasir Mas dan bercerai pada 16 Julai 2002 di Mahkamah Rendah Syariah Kemaman, Terengganu dengan talak kali pertama. Hasil daripada perkahwinan tersebut, mereka telah dikurniakan dengan dua orang anak perempuan. Sepanjang tempoh perkahwinan, Perayu adalah suri rumah tangga sepenuh masa dan Responden adalah seorang jurutera. Selama tempoh perkahwinan, Perayu dan Responden berjaya memperolehi aset-aset berikut:

(1) Harta Tak Alih

(a) Sebuah rumah dalam Lot 20158 Mukim Setapak, Kuala Lumpur atau No. 35 Jalan Wangsa Perkasa 6 Wang Melawati, 53300 Kuala Lumpur, yang bernilai RM 280,000.

(2) Harta Alih
(a) Wang KWSP berjumlah RM 300,000.00
(b) ASB sebanyak RM 20,000.00
(c) Kereta Volvo yang bernombor pendaftaran JAW 9009 yang bernilai RM $4,500.00$
(d) Sewa rumah sebanyak RM 18,000.00
(e) World Card dengan nilaian RM 10,000.00
Dalam kes ini Perayu telah memfailkan rayuan kerana tidak berpuas hati terhadap keputusan Hakim Mahkamah Tinggi Syariah Kota Bharu pada 3 Mei 2006 yang telah memutuskan bahawa 1/4 nilai rumah diberikan kepada Perayu 
dan bakinya kepada Responden. Rumah tersebut hendaklah dinilai bermula rumah itu diperolehi sehingga mereka bercerai atau dinilai bermulanya bayaran bulanan RM 1,094.00 sehingga mereka bercerai.

\section{ISU DALAM KES}

Isu di dalam kes ini ialah:

(i) Sama ada rumah teres dua tingkat tersebut adalah sabit sebagai harta sepencarian ataupun tidak.

(ii) Jika sabit sebagai harta sepencarian, berapakah kadar yang patut dapat kepada perayu.

\section{PENGHAKIMAN KES MAHKAMAH RAYUAN SYARIAH KELANTAN}

Mahkamah Rayuan Syariah telah sebulat suara membenarkan rayuan perayu berhubung harta tak alih iaitu sebuah rumah teres dua tingkat yang beralamat di No. 35 Jalan Wangsa Perkasa 6 Wang Melawati, 53300 Kuala Lumpur. Rumah tersebut bernilai bersih sebanyak RM 280,000.00 disabitkan harta sepencarian antara Perayu dan Responden dan Mahkamah memutuskan 1/3 daripada nilai tersebut iaitu sebanyak RM 93,334.00 diberikan kepada Perayu iaitu Norhayati binti Yusoff. Manakala perintah-perintah lain adalah dikekalkan kecuali pembayaran balik sebanyak RM 15,000.00 diketepikan.

\section{ULASAN KES}

Kes ini merupakan kes rayuan harta sepencarian melibatkan harta tak alih antara Perayu dan Responden. Perayu telah tidak berpuas hati dengan keputusan yang dibuat oleh Yang Arif Hakim Mahkamah Tinggi Syariah Kota Bharu, Kelantan apabila memutuskan $1 / 4$ daripada nilai rumah di No. 35 Jalan Wangsa perkasa 6 Wang Melawati, 53300 Kuala Lumpur. Tiada rayuan lain yang dibuat oleh perayu terhadap harta-harta yang lain memandangkan YA Hakim Mahkamah Tinggi Syariah telah membenarkan tuntutan perayu. Ringkasnya, harta-harta yang dituntut oleh Perayu dan jumlah bahagian yang diberikan kepada Perayu oleh Mahkamah Tinggi Syariah Kota Bharu adalah sebagaimana dalam jadual berikut: 
Jadual 1: Senarai Harta dan Bahagian yang diperolehi oleh Perayu

\begin{tabular}{|c|c|l|c|}
\hline Bil. & Jenis Harta & \multicolumn{1}{|c|}{ Harta } & $\begin{array}{c}\text { Bahagian } \\
\text { (Perayu) }\end{array}$ \\
\hline \multirow{5}{*}{ 1. } & \multirow{2}{*}{ Harta Tak Alih } & $\begin{array}{l}\text { Sebuah rumah dalam Lot 20158 Mukim } \\
\text { Setapak, Kuala Lumpur atau No. 35 Jalan } \\
\text { Wangsa perkasa 6 Wang Melawati, 53300 } \\
\text { Kuala Lumpur yang bernilai RM 280,000. }\end{array}$ & $1 / 4$ \\
\hline \multirow{5}{*}{2.} & \multirow{2}{*}{ Harta Alih } & $\begin{array}{l}\text { Wang KWSP berjumlah RM 300,000.00 } \\
\text { (termasuk RM 150,000.00 yang telah diambil } \\
\text { oleh pihak defendan untuk membeli rumah) }\end{array}$ & $20 \%$ \\
\cline { 3 - 5 } & $\begin{array}{l}\text { Wang Amanah Saham Bumiputra (ASB) } \\
\text { sebanyak RM 20,000.00 }\end{array}$ & $1 / 4$ \\
\cline { 3 - 5 } & $\begin{array}{l}\text { Kereta Volvo yang bernombor pendaftaran } \\
\text { JAW 9009 yang bernilai RM 4,500.00 }\end{array}$ & $1 / 4$ \\
\cline { 3 - 5 } & Sewa rumah sebanyak RM 18,000.00 & $1 / 4$ \\
\cline { 3 - 5 } & World Card dengan nilaian RM 10,000.00 & $1 / 4$ \\
\hline
\end{tabular}

Dalam kes ini sebenarnya terdapat percubaan oleh peguam pihak Responden untuk membuat rayuan balas bagi harta alih khususnya wang simpanan KWSP. Rayuan balas ini mungkin kerana terdapat fatwa daripada Majlis Fatwa Kebangsaan berhubung dengan wang KWSP tidak boleh dianggap sebagai harta sepencarian. Walau bagaimanapun, cubaan untuk membuat tuntutan balas ini telah ditolak oleh panel rayuan kerana Peguam Syarie Responden tidak memfailkan rayuan balas terhadap rayuan yang dikemukakan oleh Perayu. Cubaan membuat rayuan balas secara lisan mahupun bertulis semasa prosiding rayuan berjalan merupakan satu ketidak akuran kepada Seksyen 66 dan 67 Enakmen Tatacara Mal Mahkamah Syariah (Negeri Kelantan) 2002. Seksyen 66 tersebut telah secara jelas menyatakan:

(1) "Tiap-tiap tuntutan balas hendaklah mengandungi perkara dan butir-butir yang sama seperti pernyataan tuntutan dan hendaklah ditandatangani oleh Defendan atau Peguam Syarienya;"

(2) "Tuntutan balas tidak boleh dibuat terhadap mana-mana orang pada ketika itu bukan pihak dalam tindakan itu, tetapi jika suatu tindakan balas dibuat, suatu perintah penyatuan boleh dibuat oleh Mahkamah."

Seksyen 67 Enakmen yang sama pula menyatakan: 
(1) "Jika mana-mana defendan membuat tuntutan balas, plaintif hendaklah, jika dia berhasrat hendak membuat pembelaan terhadap tuntutan balas itu, memfailkan dan menyebabkan disampaikan kepada defendan suatu pembelaan kepada tuntutan balas itu dalam apa-apa tempoh masa yang diarahkan oleh Mahkamah";

(2) "Jika plaintif tidak mematuhi subseksyen (1), seksyen 16 hendaklah terpakai seolah-olah plaintif ialah seorang defendan..."

Ketidak patuhan kepada prosedur ini telah menyebabkan rayuan balas yang cuba dibuat oleh Peguam Syarie Responden gagal. Kepatuhan kepada sesuatu prosedur Mahkamah merupakan isu yang sangat penting kerana prosedur yang digubal bertujuan untuk melindungi hak dan keadilan pihak-pihak yang terlibat dalam sesuatu pertikaian.

Perayu dalam permohonan rayuannya telah memohon untuk mendapatkan $1 / 2$ daripada keseluruhan nilaian rumah tersebut. Perayu telah menghujahkan bahawa sumbangan yang telah diberikan olehnya adalah memadai untuk Perayu mendapat hak yang sama rata dengan Responden. Perayu merasakan nilaian 1/4 yang diberikan oleh YA Hakim Mahkamah Tinggi Syariah adalah tidak memadai. Meskipun begitu, Mahkamah Rayuan Syariah telah memberikan nilaian rumah tersebut dengan kadar 1/3 kepada pihak Perayu kerana pihak Perayu mengakui bahawa tiada sumbangan langsung yang telah diberikan olehnya. Oleh kerana itulah Mahkamah Rayuan Syariah memberikan hak $1 / 3$ daripada nilai rumah yang dituntut kepada perayu. Ini adalah bertepatan dengan peruntukan seksyen 22 (4) Enakmen Undang-Undang Keluarga Islam (Negeri Kelantan) yang menyatakan:

“(4) Pada menjalankan kuasa yang diberi oleh subseksyen (3), Mahkamah hendaklah memberi perhatian kepada(a) takat sumbangan-sumbangan yang telah dibuat oleh pihak yang tidak memperolehi aset itu, kepada kebajikan keluarga dengan memelihara rumahtangga atau menjaga keluarga; (b) keperluan-keperluan anak-anak yang belum dewasa dari perkahwinan itu, jika ada,

dan tertakluk kepada pertimbangan-pertimbangan itu, Mahkamah boleh membahagikan aset-aset itu atau hasil jualan itu mengikut apa-apa kadar yang difikirkannya munasabah, tetapi, walau bagaimana pun, pihak yang telah memperoleh asetaset itu dengan usahanya hendaklah menerima suatu kadar yang lebih besar." 
Peruntukan ini secara jelas memberi panduan kepada Mahkamah untuk mempertimbangkan satu kadar yang lebih besar diberikan kepada pihak-pihak yang mengusahakan sesuatu harta dengan usaha tunggal pihak tersebut.

Dalam isu wang KWSP, meskipun sudah terdapat fatwa di peringkat kebangsaan yang menyatakan bahawa wang KWSP bukanlah harta sepencarian, namun fatwa tersebut tidaklah mengikat Mahkamah Syariah Negeri Kelantan sehinggalah fatwa tersebut diwartakan di peringkat negeri Kelantan. Sehingga itu Hakim Mahkamah Syariah boleh berijtihad dan mengeluarkan pandangan sendiri dalam penghakiman kes-kes yang melibatkan tuntutan wang KWSP. Dalam kes ini pula, tuntutan terhadap harta sepencarian dibuat lebih awal daripada keputusan Majlis Fatwa Kebangsaan berhubung dengan isu wang KWSP sebagai harta sepencarian.

Majlis Fatwa bersidang pada bulan Februari 2005 dan keputusan kes ini pula adalah pada Mei 2006, dan fatwa tersebut belum diwartakan di negeri Kelantan yang menyebabkan Mahkamah tidak terikat dengan keputusan fatwa tersebut. Majlis Fatwa Kebangsaan dalam fatwa yang dikeluarkan pula hanya mengekalkan fatwa yang pernah dikeluarkan pada tahun 2000 berhubung status wang KWSP sebagai harta pusaka. Keputusan Majlis Fatwa Kebangsaan yang bersidang pada 22 Februari 2005 yang antara lain menyatakan bahawa:

"Muzakarah Jawatankuasa Fatwa Kebangsaan Bagi Hal Ehwal
Ugama Islam Malaysia kali ke-67 pada 22 Februari 2005 di
Putrajaya telah membincangkan hukum menjadikan caruman
Kumpulan Wang Simpanan Pekerja (KWSP) sebagai Harta
Sepencarian. Dalam persidangan ini, muzakarah bersetuju
mengekalkan sepertimana keputusan yang lepas iaitu wang
caruman KWSP tidak boleh dianggap sebagai harta sepencarian
dan menetapkan wang tersebut sebagai harta pusaka yang perlu
dibahagikan mengikut hukum faraid..."

Walaupun perbincangan isu KWSP ini telah dibuat, namun beberapa pandangan yang berbeza masih boleh dikaji. Sementelahan pula, KWSP telah dianggap sebagai harta perkahwinan di Mahkamah Sivil melalui kes Ching Seng Woah lwn. Lim Shook Lin. ${ }^{2}$ Sebenarnya, peruntukan tentang tuntutan dan pembahagian harta sepencarian yang digubal kepada orang Islam dan bukan Islam adalah hampir sama melalui undang-undang yang berbeza iaitu Akta Undang-undang Pembaharuan (Perkahwinan dan Perceraian) 1976 [Akta 164] untuk orang bukan Islam dan Undang-undang Keluarga Islam

2 Ching Seng Woah lwn. Lim Shook Lin [1997] 1 MLJ 109. 
yang digubal di negeri-negeri untuk orang-orang Islam. ${ }^{3}$ Namun, apa yang penting dalam kes ini ialah Hakim Mahkamah Tinggi Syariah Kota Bharu tidak terikat dengan fatwa yang dikeluarkan oleh Majlis Fatwa Kebangsaan berkenaan dengan wang KWSP sebagai harta sepencarian. Hakim Mahkamah Tinggi dalam penghakimannya berpendapat ada hak isteri yang boleh dituntut dalam wang KWSP. Keadaan isteri yang tidak bekerja tetapi menjaga rumah tangga dengan baik, memelihara kehormatan serta melayani suami dengan baik telah menimbulkan ketenangan dalam rumah tangga sehingga suami dapat menjalankan pekerjaan dengan baik. Hasil daripada ini, suami mendapat bayaran gaji yang baik serta mempunyai simpanan yang dan caruman yang baik di KWSP. Oleh yang demikian, Hakim Mahkamah Tinggi Syariah berpendapat isteri tetap berhak untuk mendapat bahagian dalam harta sepencarian.

Rayuan balas oleh pihak Responden dalam isu wang KWSP pula telah ditolak kerana kesilapan prosedur pihak peguam syarie Responden. Oleh yang demikian, tiada penilaian keputusan yang boleh dianalisis daripada Mahkamah Rayuan Syariah Kelantan berhubung dengan isu wang KWSP sebagai harta sepencarian ini. Jika rayuan balas ini dibenarkan, mungkin kita akan dapat melihat pendirian Mahkamah Rayuan Syariah Kelantan berhubung isu wang KSWP ini.

\section{KESIMPULAN}

Kes ini merupakan siri-siri kes harta sepencarian yang menunjukkan sumbangan tak langsung dalam harta sepencarian adalah yang diiktiraf oleh Mahkamah Syariah Malaysia. Malah, Mahkamah Syariah sedaya upaya cuba untuk memaksimumkan hak dan bahagian yang diperolehi oleh pihak-pihak dalam pertikaian harta sepencarian. Selain itu, fatwa-fatwa yang dikeluarkan tetapi tidak digazetkan di peringkat negeri tidak akan mengikat Mahkamah untuk mengeluarkan keputusan dalam sesuatu kes. Memandangkan harta sepencarian juga bukanlah sesuatu yang qat ${ }^{\prime} \bar{l}$ dalam hukum syarak, maka undang-undang yang berkuatkuasa masih membenarkan ruang-ruang ijtihad yang bersesuaian dengan sesuatu kes.

Kepatuhan prosedur yang ditetapkan oleh undang-undang juga menjadi elemen paling penting dalam sesuatu kes. Kegagalan mematuhi prosedur akan menyebabkan ruang dan maksud keadilan dalam sesebuah undangundang tidak akan dicapai dengan sempurna. Oleh yang demikian, adalah menjadi sesuatu yang penting untuk semua pihak mematuhi prosedur

3 Rujukan lanjut sila lihat analisis Jane Connors (1988-1989), "Malaysian Responding to Religious and Cultural Pluralism", Journal of Family Law, vol. 27. 
sebelum membincangkan isu-isu substansif sesuatu kes yang dikemukakan oleh Mahkamah. Kes ini juga menunjukkan perkembangan tuntutan harta sepencarian dalam bentuk harta-harta "moden" seperti saham-saham di ASB dan World Card (kad pelancongan). Ini menunjukkan perkembangan tuntutan harta sepencarian tidak lagi terhad kepada harta-harta tradisional seperti tanah dan rumah sahaja. 